Supporting Information 
The Tremella-Like Mo and N Co-Doped Graphitic Nanosheets by InSitu Carbonization of Phthalocyanine for Potassium-Ion Battery

Kang $\mathrm{Li}^{\text {a b }}{ }^{\mathrm{b}}$, Jianfeng Zhu ${ }^{\text {a*}}$, Zhanwei Xu ${ }^{\text {a }}$, Qianqian Liu ${ }^{\mathrm{a}}$, Shengli Zhai ${ }^{\mathrm{b}}$, Na Wang ${ }^{\mathrm{b}}$, Xiaoxian Wang $^{\mathrm{c}}$, Zhi Li ab*

a School of Materials Science and Engineering, Shaanxi Key Laboratory of Green Preparation and Functionalization for Inorganic Materials, Shaanxi University of Science and Technology, Xi'an, 710021, People's Republic of China

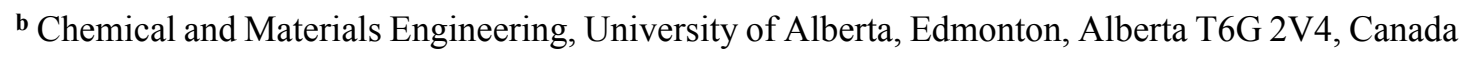
' Shaanxi Coal Chemical Industry Technology Research Institute Co., Ltd, Xi'an, 710070, People's Republic of China

E-mail: zhujf@sust.edu.cn, zhi.li@ualberta.ca 


\section{Chemical structures of CoTAP}

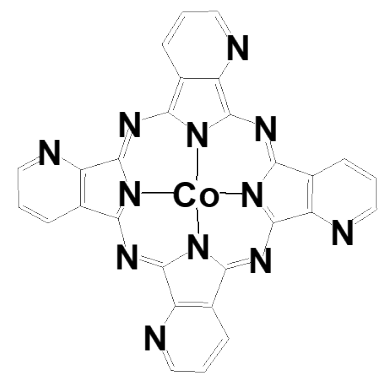

Figure S1. Chemical structures of CoTAP.

\section{Materials}

$\mathrm{CoCl}_{2} \bullet 6 \mathrm{H}_{2} \mathrm{O}$, urea and $\left(\mathrm{NH}_{4}\right)_{6} \mathrm{Mo}_{7} \mathrm{O}_{24} \bullet 4 \mathrm{H}_{2} \mathrm{O}$ were bought from Sinopharm Chemical Reagent Co., Ltd. 2,3-pyridinedicarboxylic acid (99.0\%) was produced by Alfa Aesar. Activated carbon was provided by Shaanxi Coal Chemical Industry Technology Research Institute Co., Ltd. Nitric acid $\left(\mathrm{HNO}_{3}, 65.0 \sim 68.0 \%\right)$ and with hydrochloric acid ( $\mathrm{HCl}, 36.0 \%-37.0 \%)$ were analytical purity from Sinopharm Chemical Reagent Co., Ltd. Thionyl chloride electrolyte $\left(\mathrm{SOCl}_{2}, 99.5 \%\right)$, acetylene black and PTFE solution (60\%) were provided from Chengdu Jianzhong Lithium Battery Co., Ltd. All other reagents were used for analytical purity. 


\section{Synthesis of AC-F}

Pour $100 \mathrm{~mL}$ of water and $50 \mathrm{~mL}$ of $\mathrm{HNO}_{3}$ into a $250 \mathrm{~mL}$ beaker and stir well with a glass rod. $2.00 \mathrm{~g}$ activated carbon was washed and dried with deionized water. Transfer the activated carbon into the $4 \mathrm{~mol} / \mathrm{L} \mathrm{HNO}_{3}$ solution and stir it in a water bath at $60{ }^{\circ} \mathrm{C}$ for $24 \mathrm{~h}$. The product was washed with deionized water and dried at $110{ }^{\circ} \mathrm{C}$ for $12 \mathrm{~h}$ to obtain functional-activated carbon (AC-F).

\section{Synthesis of CoTAP/AC-F composites}

0.20g AC-F, 0.41 g 2,3-pyridinedicarboxylic acid, $0.31 \mathrm{~g} \mathrm{CoCl}_{2} \bullet 6 \mathrm{H}_{2} \mathrm{O}, 0.60 \mathrm{~g}$ urea, and $0.06 \mathrm{~g}\left(\mathrm{NH}_{4}\right)_{6} \mathrm{Mo}_{7} \mathrm{O}_{24} \bullet 4 \mathrm{H}_{2} \mathrm{O}$ were mixed in a mortar. Grind the materials for half an hour. The mixture was heated in a muffle oven at $140{ }^{\circ} \mathrm{C}$ for half an hour and $270{ }^{\circ} \mathrm{C}$ for two hours, then cooled to room temperature. The obtained product was immersed in deionized water and stirred. After standing for a while, the upper waste liquid was poured out. Then the product was washed with acetone and ethanol and put into a drying oven at $105^{\circ} \mathrm{C}$ for 12 hours.

\section{Synthesis of $\mathrm{Mo}_{2} \mathrm{C}-\mathrm{MoC} / \mathrm{AC}-\mathrm{N}-1$ composites}

0.20g AC-F, $0.205 \mathrm{~g}$ 2,3-pyridinedicarboxylic acid, $0.155 \mathrm{~g} \mathrm{CoCl}_{2} \bullet 6 \mathrm{H}_{2} \mathrm{O}, 0.30 \mathrm{~g}$ urea, and $0.03 \mathrm{~g}\left(\mathrm{NH}_{4}\right)_{6} \mathrm{Mo}_{7} \mathrm{O}_{24} \bullet 4 \mathrm{H}_{2} \mathrm{O}$ were mixed in a mortar. Grind the materials for half an hour. The mixture was heated in a muffle oven at $140{ }^{\circ} \mathrm{C}$ for half an hour and $270{ }^{\circ} \mathrm{C}$ for two hours, then cooled to room temperature. The obtained product was 
immersed in deionized water and stirred. After standing for a while, the upper waste liquid was poured out. Then the CoTAP/AC-F-1 was washed with hydrochloric acid (4 $\mathrm{mol} / \mathrm{L}$ ), acetone and ethanol and put into a drying oven at $105{ }^{\circ} \mathrm{C}$ for 12 hours. The second step was to heat the CoTAP/AC-F-1 in a tube furnace with argon gas at $650{ }^{\circ} \mathrm{C}$ for half an hour and $975{ }^{\circ} \mathrm{C}$ for two hours, then cooled to room temperature. The obtained $\mathrm{Mo}_{2} \mathrm{C}-\mathrm{MoC} / \mathrm{AC}-\mathrm{N}-1$ composites were washed with acetone and ethanol and put into a drying oven at $105^{\circ} \mathrm{C}$ for 12 hours.

\section{Synthesis of $\mathrm{Mo}_{2} \mathrm{C}-\mathrm{MoC} / \mathrm{AC}-\mathrm{N}-2$ composites}

0.20g AC-F, 0.615 g 2,3-pyridinedicarboxylic acid, $0.465 \mathrm{~g} \mathrm{CoCl}_{2} \bullet 6 \mathrm{H}_{2} \mathrm{O}, 0.90 \mathrm{~g}$ urea, and $0.09 \mathrm{~g}\left(\mathrm{NH}_{4}\right)_{6} \mathrm{Mo}_{7} \mathrm{O}_{24} \bullet 4 \mathrm{H}_{2} \mathrm{O}$ were mixed in a mortar. Grind the materials for half an hour. The mixture was heated in a muffle oven at $140{ }^{\circ} \mathrm{C}$ for half an hour and $270{ }^{\circ} \mathrm{C}$ for two hours, then cooled to room temperature. The obtained product was immersed in deionized water and stirred. After standing for a while, the upper waste liquid was poured out. Then the CoTAP/AC-F-2 was washed with hydrochloric acid (4 $\mathrm{mol} / \mathrm{L}$ ), acetone and ethanol and put into a drying oven at $105{ }^{\circ} \mathrm{C}$ for 12 hours. The second step was to heat the CoTAP/AC-F-2 in a tube furnace with argon gas at $650{ }^{\circ} \mathrm{C}$ for half an hour and $975{ }^{\circ} \mathrm{C}$ for two hours, then cooled to room temperature. The obtained $\mathrm{Mo}_{2} \mathrm{C}-\mathrm{MoC} / \mathrm{AC}-\mathrm{N}-2$ composites were washed with acetone and ethanol and put into a drying oven at $105^{\circ} \mathrm{C}$ for 12 hours. 


\section{Characterization}

XRD analysis was performed by X-ray diffractometer (XRD, Rigaku, Japan) with $\mathrm{Cu} \mathrm{K} \alpha$ radiation $(\lambda=0.15406 \mathrm{~nm})$ at $40 \mathrm{kV}$ and $40 \mathrm{~mA}$ in the $2 \theta$ range from $10^{\circ}$ to $70^{\circ}$. Raman measurements were performed on an InVia instrument using $532 \mathrm{~nm}$ diodepumped solid-state laser. Thermogravimetric analyses (TGA) were performed with a NETZSCH, STA409PC apparatus at $20-900{ }^{\circ} \mathrm{C}$ in a nitrogen atmosphere. The $\mathrm{N}_{2}$ adsorption/desorption isotherms were measured by Micromeritics ASAP 2460, the corresponding pore size distribution results were obtained by density functional theory (DFT). A scanning electron microscope (SEM, Hitachi S4800) was used to analyze the morphology of the samples. Transmission electron microscopy (TEM) analysis was performed using a FEI Tecnai G2 F20 S-TWIN at an accelerating voltage of $200 \mathrm{kV}$. X-ray photoelectron spectroscopy (XPS) analysis used an AXIS SUPRA (United Kingdom).

\section{Electrochemical test}

The anode materials were prepared by mixing $75 \mathrm{wt} \% \mathrm{Mo}_{2} \mathrm{C}-\mathrm{MoC} / \mathrm{AC}-\mathrm{N}$ composites, $15 \mathrm{wt} \%$ carbon black (Aladdin) and $10 \mathrm{wt} \%$ polyvinylidene fluoride (PVDF) binder dissolved in N-methyl-2-pyrrolidinone (NMP).Then the mixtures were coated on $\mathrm{Cu}$ foils, and anode electrodes were dried at $65{ }^{\circ} \mathrm{C}$ under vacuum overnight to remove the solvent, and then pressed and punched into a disk. The electrochemical performances were measured by assembling CR2032-type cell in an argon filled glove 
box with water and oxygen content below $0.1 \mathrm{ppm}$. The potassium metal disk (Aladdin, 99\%) was used as counter electrode, and glass microfiber (Whatman) was used as the separator. The electrolyte was $1 \mathrm{M}$ Potassium bis(fluorosulfonyl)imide (KFSI) dissolved in Dimethoxyethane (DME). Galvanostatic charge/discharge and galvanostatic intermittent titration technique were performed on a computer controlled multichannel battery testing system (LAND, China) in the voltage range of 0.01 to 2.5 V. The electrochemical impedance spectroscopy (EIS) used a PARSTAT MC Multichannel Potentiostat(PARSTAT MC 2000A, United States). The frequency range of the test is $0.01 \mathrm{~Hz}$ to $100 \mathrm{kHz}$ with 12 points per decade. Starting with the open circuit potential, the amplitude is $5 \mathrm{mV}$ and the quiet time is 2 seconds. The cyclic voltammetry $(\mathrm{CV})$ used a PARSTAT MC Multichannel Potentiostat (PARSTAT MC 2000A, United States).

\section{The SEM micrograph of carbonized CoTAP without activated carbon support}

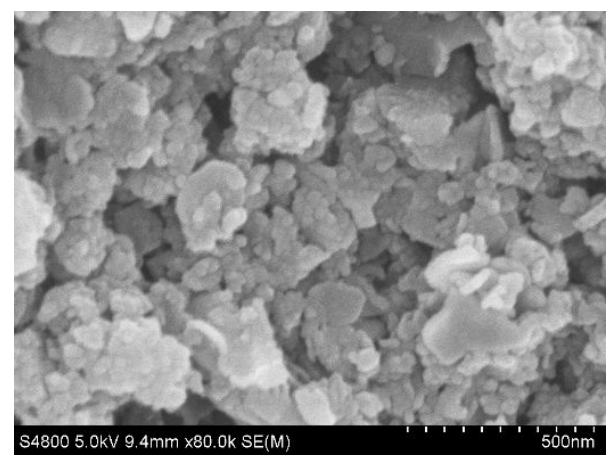

Figure S2. The carbonized CoTAP without activated carbon support. 
10. The Raman spectroscopy of CoTAP

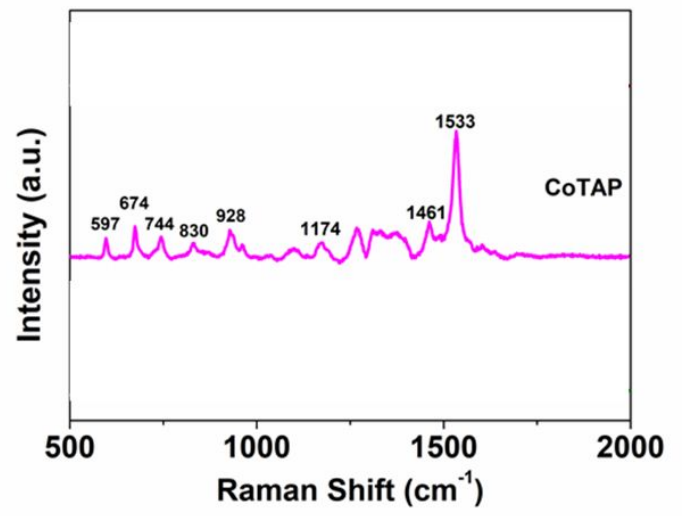

Figure S3. The Raman spectroscopy of CoTAP.

11. Observed vibrational frequencies of CoTAP and CoTAP/AC-F composites

\begin{tabular}{ccc}
\hline CoTAP & $\begin{array}{c}\text { CoTAP/AC-F } \\
\text { composites }\end{array}$ & Interpretation \\
\hline 597 & 598 & Pyridine ring deformation \\
674 & 677 & Macrocycle breathing \\
744 & 745 & Macrocycle ring stretch \\
830 & 832 & C-N aza-group stretch \\
928 & 928 & Pyridine breathing \\
1174 & 1179 & C-H bend \\
1461 & 1466 & C-N pyrrole stretch \\
1533 & 1540 & C-N aza-group stretch \\
\hline
\end{tabular}

Table S1. Observed vibrational frequencies of CoTAP and CoTAP/AC-F composites 
12. The pore size distribution of $\mathrm{Mo}_{2} \mathrm{C}-\mathrm{MoC} / \mathrm{AC}-\mathrm{N}, \mathrm{Mo}_{2} \mathrm{C}-\mathrm{MoC} / \mathrm{AC}-\mathrm{N}-1, \mathrm{Mo}_{2} \mathrm{C}-$ MoC/AC-N-2 and AC-F

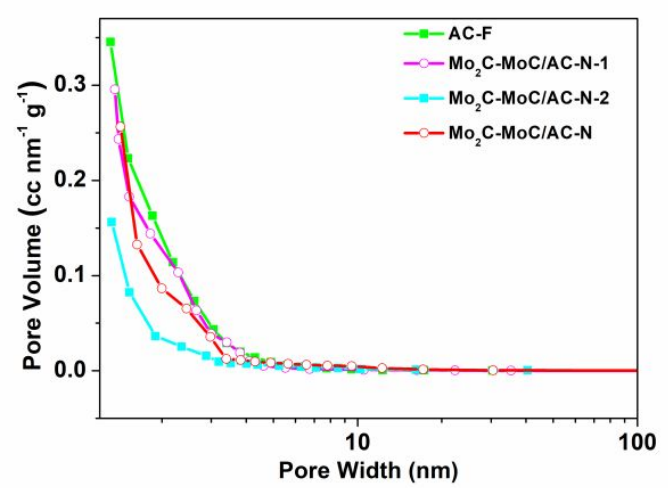

Figure S4. The pore size distribution of $\mathrm{Mo}_{2} \mathrm{C}-\mathrm{MoC} / \mathrm{AC}-\mathrm{N}, \mathrm{Mo}_{2} \mathrm{C}-\mathrm{MoC} / \mathrm{AC}-\mathrm{N}-1, \mathrm{Mo}_{2} \mathrm{C}-\mathrm{MoC} / \mathrm{AC}-$

$\mathrm{N}-2$ and AC-F.

13. The XPS analysis of $\mathrm{Mo}_{2} \mathrm{C}-\mathrm{MoC} / \mathrm{AC}-\mathrm{N}$ composites

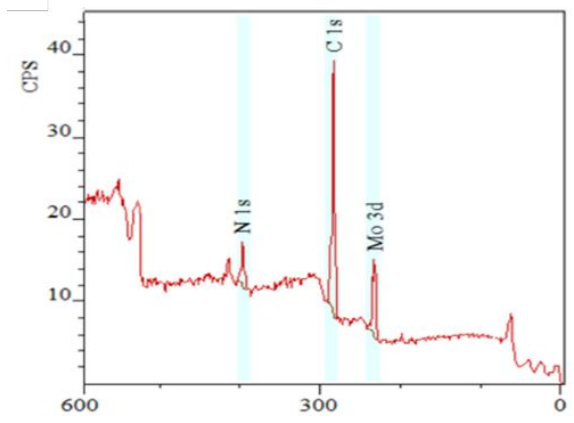

Figure S5. The overall XPS analysis of $\mathrm{Mo}_{2} \mathrm{C}-\mathrm{MoC} / \mathrm{AC}-\mathrm{N}$ composites. 
14. $\mathrm{C}$ 1s spectrum of the $\mathrm{Mo}_{2} \mathrm{C}-\mathrm{MoC} / \mathrm{AC}-\mathrm{N}$ composites.

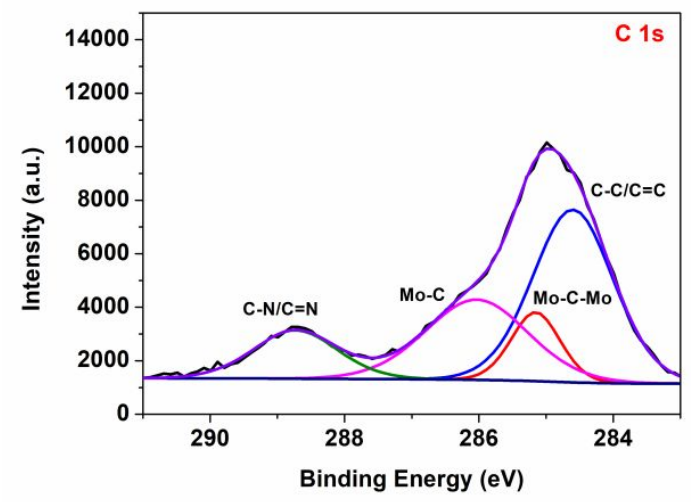

Figure S6. C 1s spectrum of the $\mathrm{Mo}_{2} \mathrm{C}-\mathrm{MoC} / \mathrm{AC}-\mathrm{N}$ composites.

15. The SEM micrograph of AC-F

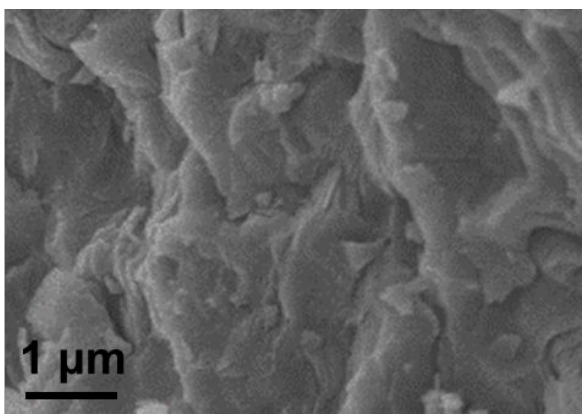

Figure S7. The SEM micrograph of AC-F. 
16. SEM micrograph of the CoTAP

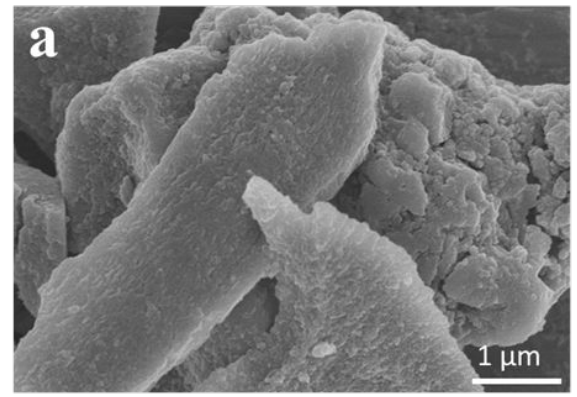

Figure S8. The SEM micrograph of the CoTAP.

17. SEM micrograph of the CoTAP/AC-F

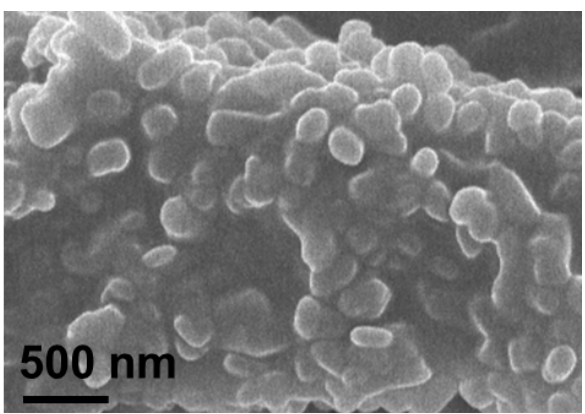

Figure S9. The SEM micrograph of the CoTAP/AC-F. 
18. SEM micrograph of the $\mathrm{Mo}_{2} \mathrm{C}-\mathrm{MoC} / \mathrm{AC}-\mathrm{N}$

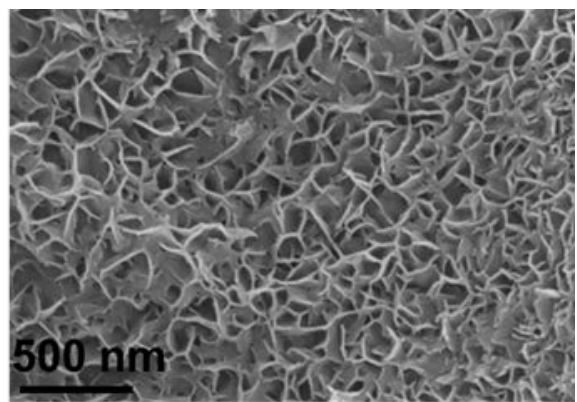

Figure S10. The SEM micrograph of the $\mathrm{Mo}_{2} \mathrm{C}-\mathrm{MoC} / \mathrm{AC}-\mathrm{N}$.

\section{SEM micrograph of the $\mathrm{Mo}_{2} \mathrm{C}-\mathrm{MoC} / \mathrm{AC}-\mathrm{N}-1$}

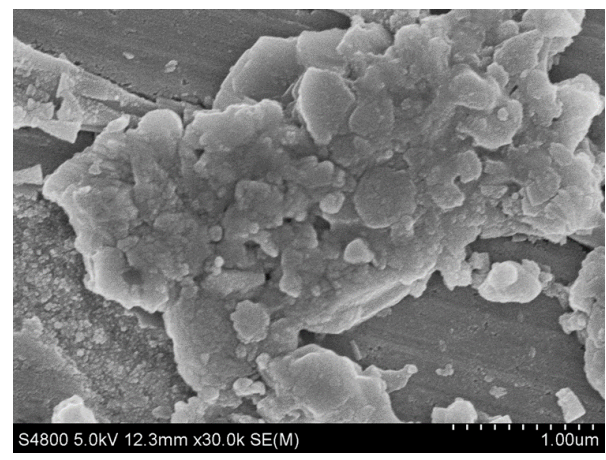

Figure S11. The SEM micrograph of the $\mathrm{Mo}_{2} \mathrm{C}-\mathrm{MoC} / \mathrm{AC}-\mathrm{N}-1$. 
20. SEM micrograph of the $\mathrm{Mo}_{2} \mathrm{C}-\mathrm{MoC} / \mathrm{AC}-\mathrm{N}-2$

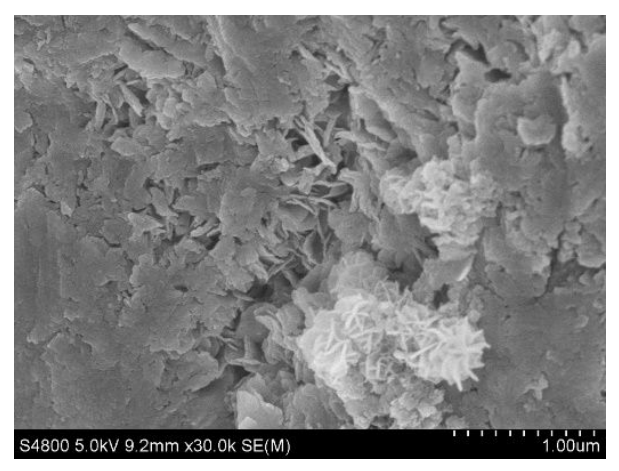

Figure S12. The SEM micrograph of the $\mathrm{Mo}_{2} \mathrm{C}-\mathrm{MoC} / \mathrm{AC}-\mathrm{N}-2$.

21. EIS curves of the $\mathrm{Mo}_{2} \mathrm{C}-\mathrm{MoC} / \mathrm{AC}-\mathrm{N}$ electrode in PIBs after different cycles (the corresponding equivalent circuit)

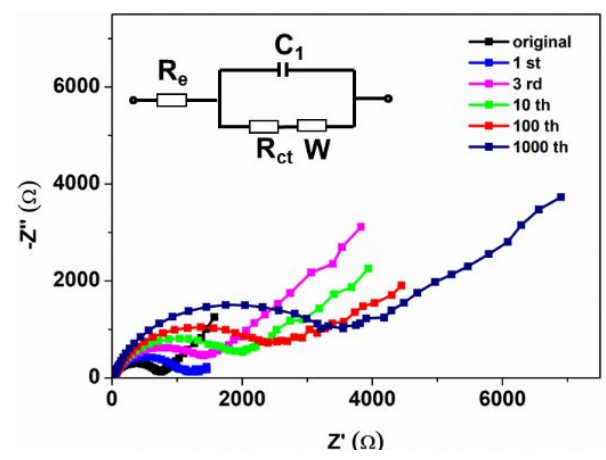

Figure S13. EIS curves of the $\mathrm{Mo}_{2} \mathrm{C}-\mathrm{MoC} / \mathrm{AC}-\mathrm{N}$ electrode in PIBs after different cycles (the corresponding equivalent circuit). 
22. The composition of $\mathrm{Mo}_{2} \mathrm{C}-\mathrm{MoC} / \mathrm{AC}-\mathrm{N}, \mathrm{Mo}_{2} \mathrm{C}-\mathrm{MoC} / \mathrm{AC}-\mathrm{N}-1, \mathrm{Mo}_{2} \mathrm{C}-\mathrm{MoC} / \mathrm{AC}-$ N-2 composites determined by EDS spectrum.

\begin{tabular}{|l|l|l|l|}
\hline & $\mathrm{Mo}_{2} \mathrm{C}-\mathrm{MoC} / \mathrm{AC}-\mathrm{N}$ & $\mathrm{Mo}_{2} \mathrm{C}-\mathrm{MoC} / \mathrm{AC}-\mathrm{N}-1$ & $\mathrm{Mo}_{2} \mathrm{C}-\mathrm{MoC} / \mathrm{AC}-\mathrm{N}-2$ \\
\hline $\mathrm{C}(\mathrm{Wt} \%)$ & 66.83 & 83.56 & 53.73 \\
\hline $\mathrm{Mo}(\mathrm{Wt} \%)$ & 24.48 & 10.64 & 29.65 \\
\hline $\mathrm{N}(\mathrm{Wt} \%)$ & 8.69 & 5.80 & 16.62 \\
\hline
\end{tabular}

Table S2. The composition of $\mathrm{Mo}_{2} \mathrm{C}-\mathrm{MoC} / \mathrm{AC}-\mathrm{N}, \mathrm{Mo}_{2} \mathrm{C}-\mathrm{MoC} / \mathrm{AC}-\mathrm{N}-1, \mathrm{Mo}_{2} \mathrm{C}-\mathrm{MoC} / \mathrm{AC}-\mathrm{N}-2$ composites determined by EDS spectrum.

23. The adsorption energy of $\mathrm{K}^{+}$intercalated into $\mathrm{Mo}_{2} \mathrm{C}$ and $\mathrm{MoC}$

\begin{tabular}{|l|l|l|l|}
\hline $\mathrm{Mo}_{2} \mathrm{C}$ & $\mathrm{A}$ & $\mathrm{B}$ & $\mathrm{C}$ \\
\hline $\mathrm{E}_{\mathrm{ad}}(\mathrm{eV})$ & -1.52 & -1.53 & -1.54 \\
\hline
\end{tabular}

Table S3. The adsorption energy of $\mathrm{K}^{+}$intercalated into $\mathrm{Mo}_{2} \mathrm{C}$

\begin{tabular}{|l|l|l|l|l|}
\hline MoC & D & E & F & G \\
\hline $\mathrm{E}_{\text {ad }}(\mathrm{eV})$ & -2.10 & -1.22 & -1.21 & -2.24 \\
\hline
\end{tabular}


Table S4. The adsorption energy of $\mathrm{K}^{+}$intercalated into MoC

24. The discharge/charge profiles of the $\mathrm{Mo}_{2} \mathrm{C}-\mathrm{MoC} / \mathrm{AC}-\mathrm{N}$ in PIBs at $5 \mathrm{~A} \mathrm{~g}^{-1}$

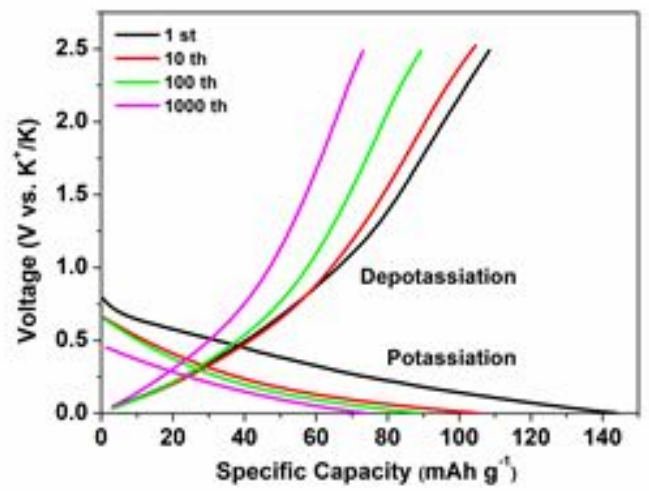

Figure S14. The discharge/charge profiles of the $\mathrm{Mo}_{2} \mathrm{C}-\mathrm{MoC} / \mathrm{AC}-\mathrm{N}$ in PIBs at the current density of $5 \mathrm{~A} \mathrm{~g}^{-1}$. 